\title{
Zonal Constructed Language Contacts and Positive Globalisation
}

\author{
Emil Heršak \\ ORCID: 0000-0002-9536-2746 \\ University of Zagreb, Faculty of Humanities and Social Sciences
}

Received 17 November 2017 • Revised 15 November 2017 • Accepted 25 November 2017

\section{Abstract}

This paper deals with languages and culture, zonal constructed language forms and world-wide globalisation. The link between language and culture is stressed in the first part of the paper, and the connection between language, culture and development is likewise noted. An intense development phase in technology (linked, it would seem, also to extensive language and culture diversity) occurred in the $19^{\text {th }}$ century, yet afterward - and especially when English became dominant in the world, development (overall technical development) became less innovative. At the end of this paper, the author states that zonal constructed languages can be a new form in which to intensify linguistic and cultural ties throughout the world, and motivate positive globalisation.

Keywords: language, culture, (technical) development, globalisation, zonal constructed languages.

\section{Introduction}

In this paper, the intent is to accentuate a form of globalisation, based on preserving the positive levels of human diversity, as opposed to a one-way direction in the present dominant globalisation ideology, which results in serious reductions as well as problems in ideas and cultural schemes (and likewise in educational, as well as in scientific and political results).

What is the root cause of the problem?

The present wide-range imposition of the English language in various international or "global" communication arrangements, in spoken and written forms, has produced this serious problem. A few decades ago, up until the 1980s, such a negative tendency was not yet fully in effect. However, as it seems, the ideology of imposing English as a world language was already advocated by certain Anglo-American authors or politicians in the late $19^{\text {th }}$ century, as well as during the $20^{\text {th }}$ century and in our millennium era ${ }^{1}$. There were likewise many European non-English (or non-

${ }^{1}$ The British politician Winston Churchill (1874-1965), who also had a role in defining the division of West Europe from the "Eastern Bloc", was for the dominance of the USA in the world (his mother was from the USA, so he probably saw this state as a British continuation), and he was also for the expansion of English over the world (see http://www.linguistic-rights.org/robert-phillipson/). In this sense, he published a series of works under the title A History of the English-speaking Peoples, vol. 1-4 (Cassell, 1956-58).

(C) Authors. Terms and conditions of Creative Commons Attribution 4.0 International (CC BY 4.0) apply. Correspondence: Emil Heršak, Faculty of Humanities and Social Sciences, Department of Ethnology and Cultural Anthropology, Ivana Lučića 3, 10000 Zagreb, HR. E-mail: hersakemil123@gmail.com. Tel: +385981777880 . 
British) emigrants, who, for various reasons, ended up in overseas English-speaking countries, and by eliminating their own (non-English) languages intensified the role of English in the world. In some cases they even took steps to eliminate their own languages, at least in the foreign areas that they settled ${ }^{2}$. This was an additional ideological move, due to personal factors, which probably in most cases did not take into consideration the wider aspect of language relations, or what would be the result when just one specific language, in this case English, would become dominant in the wider world.

\section{Language and culture}

It is first necessary to review the significance of language.

In many scientific works, there have been different interpretations in regard to the concept of "language" in various cultural or ethnic areas, in diverse sciences, especially in linguistic or cultural anthropology. Yet there is one conclusion, by a very important scientist (principally a geneticist), which is most probably exact. In his book Genes, Peoples and Languages (in the earlier Italian version entitled: Geni, popoli e lingue, which was perhaps more original and more precise, and which was used in this article)3, Luigi Luca Cavalli-Sforza (1922-) stated that language is the basis of culture (1996: 251).

Language connects people together by way of thought-exchange, and this makes it possible for groups to generate and/or shift various ideas and effects (cultural, anthropological) that are crucial for the maintenance of social unity. In short, such collective ideas and their effects can be defined as cultural factors. However, as can be deduced by reviewing the relative scientific literature, many various definitions or usages of the term "culture" exist, which are, at times, quite problematic in their meaning. The origin of the term, from the Latin verb colere (participle $\mathrm{m}$. = cultus), at first had an agricultural connotation ("to process, to cultivate" land), but the important philosopher, politician and writer Marcus Tulius Cicero (106-43 BC), in his series of works Tusculanae Disputationes (completed near the unfortunate end of his life) and dealing with stoic ideas, introduced the new term cultura animi, "cultivation of the soul". This shift in meaning increased in the centuries that followed and in our modern era finally led to various anthropological concepts, in which cultures were crucial in social or ethnic groupings. For example, one key definition of culture by Alfred Louis Kroeber (1876-1960) and Clyde Kluckhohn (1905-1960) concluded that culture includes a set of patterns of behaviour acquired and transmitted through symbols and handicrafts (through language and also art), based on traditional ideas and values, that are distinctive for certain human groups (see 1952: 47). Kroeber and Kluckholn expressed this view, after they had reviewed a large number of different definitions of culture $^{4}$. Later, another important anthropologist, Clifford James Geertz (1926-2006) defined culture as "an historically transmitted pattern of meanings embodied in symbols, a system of inherited conceptions expressed in symbolic forms by means of which men communicate, perpetuate, and develop their knowledge about and attitudes toward life" (1973: 89).

Although these anthropological definitions of culture are perhaps broader than the conclusion that Cavalli-Sforza gave, nevertheless we can deduce that they also imply that language is a basis of culture, or more precisely language is the initial basis of culture. Language can

\footnotetext{
${ }^{2}$ One minor such example occurred in Kenaston, Saskatchewan (Canada), were was a large portion of Croatian migrants - and one of them, who was in an influential position, apparently motivated them to give up Croatian and use only English.

${ }^{3}$ The English version was in fact translated from the French edition, which was published in 1996, in the same year as the Italian original.

${ }_{4}^{4}$ Apparently they reviewed 200 previous definitions of culture (Ivanović, 2008: 21).
} 
certainly be defined as an initial form of symbolism, through words (or well as figurative sounds), which can later be linked to other forms of symbolism (writing, and even to other meaningoriented symbolic versions)5.

Culture, however, has further implications.

Populations with "more or less" consistent and continuous cultural frameworks often develop into ethnicities, i.e. "ethnic groups", "peoples” or nations. The Greek term ह̌ $\theta v o \varsigma$ (originally fí⿱㇒冋os) seems to have had the basic meaning "togetherness" or "group[ness]", and therefore the Greeks used it also for "hordes of [grouped/swarmed] bees", yet it did more or less also receive the meaning "nation". This can be seen especially in the original Greek New Testament

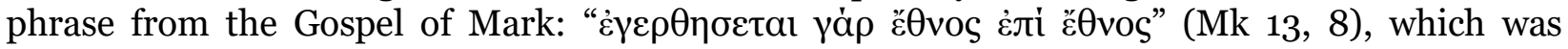
translated into English in the King James version (1611) as: "For nation shall rise against nation" (very similar to the French phrase: Une nation s'élèvera contre une nation, and different than Luther's use of the German form Volk, "folk" in this case). In the earlier translations है $\theta$ vo became gens in the early Latin translation, and several centuries later in the first Old Church Slavonic version the phrase "language", i.e. językъ (азыкъ) was used as a translation of $\varepsilon \theta$ vos (the cited phrase Mk 13, 8 became “въстанетъ бо ғзыкъ на ғзыка" in Old Church Slavonic). In the Slavic area of Europe this tradition continued in Croatia for many centuries. The best example was the text by the Glagolitic Croatian priest Martinac regarding the year 1493 (after the Battle of Krbava Field), in which he described the Ottoman invasion, by saying that their force "came down onto the Croatian language" (nalegoše na jazik hrvatski). The "Croatian language", here, was the "Croatian nation [or the Croatian हैंvos]".

In the above-mentioned Slavic case the use of the word or term "language" (językz) for "ethnicity" or "nationality" is probably linked to the origin of the ethnic phrase "Slav" (Sloverninz), which, as it seems, implies that a population has a common language structure or a joint language understanding 6 . In fact, if we examine the various genetic or other tendencies in the Slavic world, in the past and present, it is still very obvious that the criteria for defining this super-ethnic group, is primarily linguistic, and often not the result of genetic tendencies, or other inherited historical factors?.

\footnotetext{
${ }^{5}$ There is also a term "proto-writing" which appeared, it seems, first in English science works and which is, not exactly clear, and it seems not exact (see, https://en.wikipedia.org/wiki/Proto-writing). The present lack of knowledge as to the meaning of previous symbols should not be used as a definition criteria.

${ }^{6}$ In present Slavic languages, the "root form" slov- is used in most of these languages (in Czech, Polish, Slovakian, Slovenian, Serbian, Sorbian, Macedonian and Ukrainian), and slav- in the other ones (in Bulgarian, Belarusian, Croatian, and Russian). The first "root form" has often been linked to slovo, "word", or slovg, sluti "to talk understandingly, to be mentioned", whereas the other "root form", slav-, might mean "glorious" (slava), but this phrase may possibly be derived from the root klōu-, "to hear", or it could be a phonetic shift from slov- (for some other explanation, see Gluhak, 1993: 558-561).

7 One classical example is the "Croat-Serbian connection". As far as some analyses have shown, DNA differences between Croats and Serbs are more pronounced than such data between other neighbouring peoples in Europe. The Serbs seem to be much more "Balkan" and closer to the Albanians, etc. than to some Croats, although Croats are also very much divided genetically, especially between the populations in the Northern or North-West areas and those along the Adriatic coast and the Dinaric mountains. The Northern and North-west populations are close to the Slovene, Slovak and somewhat to the Hungarian populations, whereas the Adriatic and Dinaric populations, have archaic DNA characteristics, going back even to the Palaeolithic era! However, regardless of these DNA differences, the language similarity between Croats and Serbs (and also Bosnians and Montenegrins) is very high. Language, therefore, was the key element in stimulating contacts, and as well as in expanding certain cultural ties, between populations that had difference genetic (or in general "related") links.
} 
Throughout history, since language is the basis of culture, it seems that linguistic similarities have produced cultural ties, yet at times even close ties have brought about conflicts. In the Slavic world this occurred between Serbs and Croats, who through time developed a very close linguistic tie (especially in the $20^{\text {th }}$ century). In addition - as we know - there were very serious conflicts between Poles and Russians, although these two populations were much closer linguistically, one to the other, than either was to Germanic, Romance (Latin-based) or AngloAmerican groups. There were major conflicts between nations from many other language groups. Conflicts occurred between Germanic groups (in Central Europe and between nations in Scandinavia), and among various Romance populations. The Anglo-American world in its own "English" context experienced numerous conflicts and wars, for the most part from the end of the $18^{\text {th }}$ to the middle of the $19^{\text {th }}$ century.

\section{Language, culture and development}

The previous statements may appear contradictive.

First, the thesis that language is the basis of culture was emphasised. Language and culture were tied (more or less) to ethnic or in general to groups of population, and finally conflicts between linguistically similar ethnic or national populations were briefly noted. However, aside from conflicts or wars (such as those that occurred between the British and Anglo-Americans, between the Spanish and their colonies, etc.), within Europe, at least in the $19^{\text {th }}$ century, languages that either had close ties to one another, or quite different ones, began to receive special status in numerous countries. Many such cases in Europe, during the $19^{\text {th }}$ century, brought about official "national languages" in various states or regional zones. Finnish, for example, became official for the first time in the Grand Duchy of Finland in the Russian Empire ${ }^{8}$. Italian was unified and expanded as a language following the intervention of Napoleon Bonaparte (1769-1821) into Italy in the early $19^{\text {th }}$ century. Croatian became official, instead of Latin, in the Croatian Parliament in 1847 (which had effects in many other domains), and Polish finally replaced Latin as the official language in parts of that country in the second half of the $19^{\text {th }}$ century.

However, in the $19^{\text {th }}$ century and sometimes in the early or later $20^{\text {th }}$ century, political actions were undertaken in several countries to eliminate certain languages. Great Britain attempted at that time, and earlier as well, to eliminate the use of Celtic languages in Wales, Scotland and Ireland. In British North America (i.e. Canada), after the inflow of British loyalists following the American Revolution and later, as a result of many direct British immigrants, efforts were made to assimilate French speakers in that colony. ${ }^{9}$ British imposition of English over all other languages, occurred likewise in other colonies. In India Mahatma Gandhi (1869-1948) would ultimately conclude that English is all right to learn - if necessary, but that it should not become an overriding language. In the United States, during the $19^{\text {th }}$ and $20^{\text {th }}$ century English was also massively imposed. The various defeated native Amerindians in this country were forced to give up their languages (their children were taken away from their parents and were placed in schools where

\footnotetext{
${ }^{8}$ The Grand Duchy of Finland was an autonomous region in the Russian Empire from 1809 (by choice of its nobility) until 1917, when the country became independent. Finland likewise received special advantages in (Finnish) education during the reign of Alexander II Romanov (1818-1881, emperor 1855-1881). Alexander also re-established the Diet of Finland, and his statue is for this reason (in honour of him) located even today in front of the Finnish Parliament in Helsinki.

9 There were, of course, some moves towards respecting French in Canada, but bilingualism in Canada became official only in 1969, whereas other languages, including native ones, did not have official statuses in most cases. Yet relatively recently some native languages in Canada, but only in the Northwest Territories (Chipewyan, Cree, Gwich'in, Inuinnaqtun, Inuktitut, Inuvialuktun, North Slavey, South Slavey, Tłįchǫ) and in Nunavut (Inuit), formally gained official status.
} 
they were forbidden to speak their own languages). The war with Mexico and other events also brought about tendencies to eliminate Spanish as an alternative to English. Of course, in many other colonised or occupied areas dominant countries often tried to impose their languages on other populations. The same also occurred in some European regions, where there were attempts to produce one directional linguistic transformation.

In fact, the linguistic shifts that started more or less during the $19^{\text {th }}$ century were connected to the new concept of nationalism, which became intense in that period, after the political changes that occurred following the so-called "Age of Enlightenment", which in fact could be viewed as the last era of the so-called Mediaeval period. As we know, in the Mediaeval Period, in Europe certain languages that had received exceptional "religious" status, had become vital in communication: Latin was for a long time central in the West, Greek in Byzantium, and Old Church Slavonic had a key role in the Slavic Eastern Orthodox zones, as well as in Catholic Croatia. ${ }^{10}$ However, in the Age of Enlightenment, French authors, such as Voltaire (= François-Marie Arouet, 1694-1778), placed an emphasis on the domination of French all over the world, and there were also comments, especially by Louis Sébastien Mercier (1740-1814) that both Greek and Latin should no longer be studied, since excellent translations already existed in French (see Mercier 1771). Nationalism was obviously on the rise in the period before the French Revolution, and, as was said, a key change would happen later, after the move into the $19^{\text {th }}$ century. New technological advances, in other words a new development, would jump out of the previous cultural framework, and bring about major changes that still very much affect our lives today. Due to these vital changes in practically everything linked to technology, the French historian Jacques le Goff (19242014) concluded that the $19^{\text {th }}$ century marked the move from the Mediaeval Period to the Modern Age (1982: 81).

First, what were the new technical inventions?

Apart from the effective steam engine that James Watt (1736-1819) created earlier, in 1781, and which helped to introduce the Industrial Revolution, other new inventions that were crucial were locomotive systems, time divisions, the first photograph techniques in the 1820s which would free art from direct illustrations, the first computers in 1833 (by Charles Babbage, 1791-1871), telegraph signals in 1831 by Samuel Finley Breese Morse (1791-1872), the first telephone in 1876 by Alexander Graham Bell (1847-1922), the next year the first phonograph by Thomas Alva Edison (1847-1931) and in 1879 the placement of Edison's light bulbs. These "bulbs" were key factors in changing our lifestyle, although Edison had not been the first to invent them, but rather the already dominant American capitalist system enabled Edison to produce and sell his bulbs. On the other hand this system brought about a conflict between Edison and Nikola Tesla (1856-1943), born in Croatia, who made many vital discoveries (especially in the field of electricity). Furthermore we can see that there were other important new creations in the $19^{\text {th }}$ century: the German engineer Karl Benz (1844-1929) invented the first functional automobiles, and as for vital discoveries in medicine, Louis Pasteur (1822-1895) invented the first vaccines and later, in 1846, applied the earliest anaesthesia method in an operation. Then in 1896. Wilhelm Conrad Röntgen (1845-1923) completed the first example of X-ray analysis. Technical discoveries during the $19^{\text {th }}$ century went, as it seems, in all directions, and in 1897 David Schwarz (1857-1897), who was born in Hungary - but grew up in Croatia - finished in Zagreb his construction of the first airship. Unfortunately Schwarz died after this invention and his wife Melanija then sold his work to Ferdinand von Zeppelin (1838-1919). In Croatia at the time important inventions were also made by Eduard Slavoljub Penkala (1871-1922), and in science the work of Dragutin GorjanovicKramberger (1856-1936) was vital, not just because in 1899 he excavated the Neanderthal fossils

${ }^{10}$ Pope Innocent IV (Sinibaldo Fieschi, 1195-1254, pope from 1243) exceptionally permitted the use of Old Church Slavonic in Catholic "Glagolitic" masses in Croatia. 
in Krapina, but because he was the first palaeontologist who dated time periods on the basis of geological indications.

Much more could be said about all the discoveries and inventions in the $19^{\text {th }}$ century. But the point in this part of our discussion is that on the one side, during this period, languages were at times either official or were under pressure, but even this second aspect implied that very many languages existed in the $19^{\text {th }}$ century, and this expanded cultural diversity and, especially among some scientists, motivated stimulations for new ideas. In other words, the more languages we have, or at least on key levels ... the more cultural variations would appear, and this would probably, in situations with intense linguistic-cultural diversities, lead to innovative or at least new ideas, which would have a positive effect on human development.

Language differentiations can lead sometimes to conflicts, as it occurred in the $19^{\text {th }}$ century, but it should be emphasised that these differences developed in general over long periods, and their relations to other linguistic-cultural structures would have been positive, as opposed to the tendency to eliminate differences, which would be, ultimately, a reduction of knowledge. The point here is that the more languages the world has, the more various is its cultural basis and its idea structure, which could have a positive effect on future human evolution, if this diversity could not only be upheld, but also understood. Yet, there were times in the past, as has been noted often in regard to Latin, that one-language orientation was an overall direction, although actually, until the present period, this was not a general tendency in many societies, as is the case at present, when a language which is also problematic in its structure (i.e. English) is being imposed in international communication between various linguistic groups.

This brings us to another major theme.

\section{Globalisation}

What is globalisation?

According to one interpretation, the idea of globalisation appeared for the first time in Anglo-American texts in the early 1960s, although French authors in that period preferred the alternative term mondialisation (Heršak, 2003: 132). But according to one view, globalisation was a process that began earlier and led to the first major world crisis in WWI ${ }^{11}$. This would actually imply that the intensified colonisation directions in the previous $19^{\text {th }}$ century were imagined as globalisation modes. The British were at that time increasingly dominant, and images of their world domination were seen by them as a positive move. However, they were in conflict with other colonist countries, and in the central Asian areas as well as in European zones with the Russian Empire. The case of the Crimean War is well known, yet there were in continuation other problematic movements ${ }^{12}$. The USA finally would become the continuation of British expansion in

${ }^{11}$ This view was expressed by the representative of the Vatican at the first "Global Forum on Migration and Development" (GFMD), which was organised by the UN in Brussels (9-11 July 2007). The author of this paper (EH) was the representative of Croatia at this forum.

12 The British were on the Ottoman side in the Crimean War. For this reason, due to the continuous conflict with the British not only in Europe, but also in Asia, the Russian emperor Alexander II decided to sell Alaska to the USA, to order to avoid the expansion of British North America to the Russian border (this aspect is rarely mentioned, but it is quite probable). As we know, during the Crimean War, the Americans were on the Russian side. The British, at that time and later, as it would seem due to their colonist politics, developed a negative relation to Russia. And even John Stuart Mill (1806-1873), who is interpreted as a key author in regard to liberalism, identified Russian expansion (to Europe) as a misfortune, comparable to the Macedonia expansion to Greece (1961: 294). This view was quite problematic, but step by step, as a result of their own new colonialism and, the USA began to develop imperialist colonialism, which the British politicians and authors, such as Winston Churchill (see Footnote 1), would finally support. On the other 
the world, although toward the end of the $19^{\text {th }}$ century and during the early $20^{\text {th }}$ there were other attempts by some Europeans countries to impose supremacy over the world. The Germans were a key factor in this orientation; the Italians also attempted to expand their sphere, yet the Russians, after their socialist revolution, in fact shifted from the world expansion of socialism/communism, according to Marx, to a political program limited to the territory of the Soviet Union.

After WWI a number of new countries appeared in the world, and when the League of Nations was formed in 1920, many countries, as well as the colonial territories of previously victorious states became a part of this union. In this sense, we could say that the League of Nations (LN) was, in its ideological sense, the first historical attempt to create a form of overall peaceful world globalisation. And there was also a suggestion that the official language of the League would be Esperanto. It may be said that this concept was, at least theoretically, excellent, since the "international" language which Ludwik Lejzer Zamenhof (1859-1917) created was formally neutral, even though it contained certain strange structures that were not typical for natural languages - and it likewise had a somewhat problematic lexical etymology ${ }^{13}$. Yet one French politician, Léon Bérard (1876-1960), strongly opposed the used of Esperanto as an international language and undertook successful actions to eliminate courses in this language within the League of Nations ${ }^{14}$. His goal was to maintain French as the world's international diplomatic language, which was more or less effective until the second part of the $20^{\text {th }}$ century.

The rise of Fascism and Nazism in Italy and Germany after WWI in the $20^{\text {th }}$ century initiated new forms of aggression, which were also linked to world-wide expansion, although certainly not to a peaceful and egalitarian global union. The idea of dominance as a necessary action was actually the result of concepts that developed in the West, to a high degree also in the Anglo-American world. Yet WWII fortunately resulted in the defeat of the Fascists, Nazis and their Japanese allies, even though the victors in the war, especially the Americans, for the first time dropped terrible atom bombs that killed hundreds of thousands of people in Japan.

It might be said that nuclear bombs, after WWII, became one of the key factors in the world expansion of "leading" world states. More or less from the early 1950s this war element, seen as aggressive or else defensive, provoked the beginning of the "Cold War", between the USA and the Soviet Union, which lasted until its reduction in the late 1980s from the Soviet side, and finally until the break-up of the USSR in $1991^{15}$.

hand, some influential authors such as Gore Vidal (1925-2012) concluded that the US president William McKinley (1843-1901, president from 1897) initiated American colonialism and world domination, and this move previously had a very negative effect on Mark Twain (Samuel Langhorne Clemens, 1835-1910), who saw the new US world expansion as a terrible development. Twain even made a flag with human skulls to simbolise the US occupation of the Philippines. And after McKinley, the next US president, Theodore Roosevelt (1858-1919, president 1901-1909), concluded that, in order to protect the security of the USA, American specific "values" had to be projected abroad (Simms, 2014: 274). This essentially dangerous model, namely imposing US "values" on other countries and cultures, is still in action worldwide (the United States has the right to develop its own cultural scheme, if it does not violate human rights, but when it imposes its own model on the rest of the world, this leads to a negative tendency regarding natural and positive world diversities).

${ }^{13}$ Interestingly, although Zamenhof was born and lived in Slavic-speaking regions (in parts of Poland within the Russian Empire), he included a very small percentage of Slavic roots in the vocabulary of Esperanto.

${ }^{14}$ For a summary in regard to Bérard's position, see the short Internet description and the sources on the French Wikipedia (https://fr.wikipedia.org/wiki/L\%C3\%A9on_B\%C3\%A9rard_(homme_politique)\#cite note-1).

15 An excellent American SF film, "The Day the Earth Stood Still”, directed by Rober Wise (1914-2005) and completed in 1951, was an attempt to emphasize that the conflicts in the Cold War would destroy humanity. Its goal, it seems, was to eliminate American international dominance. However, the final end of the Cold War was not an American result (despite the US effects to undermine the SSSR by stimulating the Afghanistan 
The new world union, the United Nations, was established earlier, on October $24^{\text {th }}$ 1945, right after WWII, yet the Cold War was the main factor that very soon motivated the three major globalisation movements in the subsequent period: one tied to Socialism/Communism and led initially by the USSR; another linked to Capitalism and Western democracy, especially to the USA, and a third defined as a Non-Aligned Movement (NAM), and initiated by the leaders of India, Indonesia, Yugoslavia, Egypt and Ghana ${ }^{16}$. This third version would seem the best in regard to connecting various cultures in the world and producing a form of globalisation that would stimulate the overall development of humanity. But at present the Non-Aligned Movement no longer has the importance it had during the Cold War, and its membership has decreased.

What happened after the Cold War was the establishment of the final domination of the USA. This country at present has the greatest army in the world, the greatest investments in military forces, and through its military framework it developed the first computer system, which was to become the Internet. Computers were invented much earlier, but the Internet was the first key factor that affected the world.

From the start, the Internet, as well as computer programmes from the US, began to impose English on the world. English also began to dominate in Europe, although in the recent past almost all international communications were in French, and the overall scientific works, from the middle $19^{\text {th }}$ until the late $20^{\text {th }}$ century in various European languages. English also gained ground in schools, which led to a general reduction in the previous language diversity that was an important factor in learning systems.

It is important, of course, to grasp the reasons as to why English became dominant in the present historical phase, and if this dominance has any positive advantages, both for further globalisation, or for more original ideas, etc.

\section{English as an international language: the problems}

English does not have any specific traits in its structure that would make it an "international" language per se, and this is also true for other "national languages". In an excellent analysis, Anna Wierzbicka (1938-), a linguist of Polish origin in Australia emphasized that many people today do not take into consideration that English is a cultural language (2014). In her study of English as an expanded world language, she described many problems resulting from that language, which, it would seem, are the result of its specificity.

Much earlier, Edward Sapir (1884-1939), who more or less initiated anthropological linguistics (or sociolinguistics) concluded that English was a problem. His description of English was: "... behind a superficial appearance of simplicity there is concealed a perfect hornet's nest of bizarre and arbitrary usages" (1986: 53) ${ }^{17}$. Naturally, English is very complex and although there is likewise a "Basic English" (or "Simple English") which is easier to learn, understanding English fully requires many years of learning. The vocabulary of English is very diverse; its phonetics are complex and in many aspects differ from the European bases (largely due to the so-called "Great Vowel Shift" in English), and its spelling is perhaps the most difficult among European or American

war). More or less, it seems that the Cold War ended due to the new democratic attempts in the USSR initiated by the Soviet leader Mikhail Gorbachev (1931-).

${ }^{16}$ The Non-Aligned Movement was founded in 1956 on the island of Brijuni, in Croatia (in former Socialist Yugoslavia). Its leaders were Josip Broz Tito (1892-1980), Jawaharlal Nehru (1889-1964), Sukarno (19011970), Gamal Abdel Nasser (1918-1970) and Kwame Nkrumah (1909-1972).

${ }_{17}$ Sapir, which was perhaps logical at the time, supported the role of Esperanto in international communication. 
languages. And this latter aspect has led to an extremely high dyslexia rate, especially in the USA where this problem has affected $15^{-20} \%$ of the country's population ${ }^{18}$.

In short English, despite its reduction of cases and genders, is a difficult language to learn, and imposing it on other cultures would most likely bring about very negative results. But "more English" has recently been forced upon the world, and it would seem that for this reason science and world knowledge has been reduced ${ }^{19}$.

English at present is a dominant language especially in Europe, and the knowledge of other languages, which was once very intense, has been reduced. Many other formerly important European cultural aspects have entered into crisis due to this change. Original European films, for example in French, Italian, German, Polish, Czech, etc., are no longer produced with such excellent results as in previous periods. Also foreign music in many countries today is most often transmitted only in English, and even though this at times produces negative results, this tendency is still imposed. The fact that it is imposed, even though it does not always have positive results, is a strange occurrence ${ }^{20}$.

Again, we must try to understand why English is being enforced in Europe (and in other areas), although it is not an easy or effective solution to international communication. In fact, it would seem that the main reason for this has nothing to do with logic, imagination, or even science, but rather with a specific ideology oriented towards the US, that was positioned in Europe during the Cold War, and also expanded through intense (Anglo-American) TV shows that were received in many countries. One additional factor may also have been the positive economic shift which Germany accomplished after WWII, due to the country's intense links to the USA. In East Europe the reaction to Communism and to the former dominance of the Soviet Union (and probably also to the Russian language) would have been a factor ${ }^{21}$.

It should be noted that some English authors, especially from Britain, showed opposition to the domination of English in the world. Although some British authors, for example H.G. Wells (Herbert George Wells, 1866-1946) had more or less a positive view of English domination in the world, others such as Aldous Huxley (1894-1963) and George Orwell (Eric Arthur Blair, 1903-1950) did not. In his novel Brave New World (1932) Huxley imagined the

${ }^{18}$ The US Department of Health and Human Service apparently estimates that $15 \%$ of the US population has dyslexia (https://www.dosomething.org/us/facts/11-facts-about-dyslexia), although we can also find other statistics on the Internet (see https://www.dyslexiacenterofutah.org/dyslexia/statistics/).

19 The American author Bob Seidensticker (1957-), in his interesting book Future Hype, noted that in the past we were able to arrive on the Moon, but today we no longer can do this (his basic thesis was that technological development has slowed down). The forcing of English, with all its problems, may be a reason for this change, although Seidensticker only mentioned the English has dominated over Esperanto as a world language (2006: 182).

${ }^{20}$ Songs in English are non-stop present in many radio programmes in Croatia, although the leading radio station in the country, called "Narodni", transmits songs only in Croatian (or in very similar languages). In other words, pushing English songs and music through the radio does not increase the number of listeners to radio stations... or, in other words, English songs are not always seen as the best (which is logical, taking into consideration diverse cultural "music emotions", which is a normal world tendency).

${ }^{21}$ During the $10^{\text {th }}$ Congress of the European Esperantno Union (10-a Kongreso de Eŭropa esperanto unio), in Rijeka on July $7^{\text {th }}$ 2014, Milorad Pupovac (1955-), a linguistic professor at the Faculty of Philosophy in Zagreb, who is also a member of the Croatian parliament as a representative of the Serb minority, claimed that English became dominant in Europe after the expansion of the EU towards the east, which would in fact mean that populations that previously lived in Communist countries turned toward English as a new international language. Pupovac also claimed that the imposition of English was not part of a state policy, as opposed to the French strategy. However, if we review the works of Robert Phillipson it turns out that the British Council and similar British (and other) institutions did indeed force English in the world (see Phillipson, 1992). 
domination of English as a form of monotony and likewise as the destruction of literature in the future, whereas Orwell, saw the development of English as part of a general collapse or decadence in civilisation (see Orwell, 1946: 252). Even earlier, the American author Jack London (1876-1916), after having travelled through the Pacific where he heard examples of "pidgin" English, published an interesting article entitled "Too much English" (1909).

English, certainly, never turned out to be an effective "pidgin" or a lingua franca. Robert Phillipson (1942-), who in many of his works criticized the domination of English, also wrote quite an interesting article in which he introduced the term lingua frankensteinia for English (2008). But in general, the term lingua franca applies only to a reduced language (or a mixed language form) that serves for simple functions and for easy purchases, or basic travelling information, and therefore this term should not be applied to a complex language such as English, which has about 500.000 words registered in the complete Oxford English dictionary, and also a very problematic spelling system. Furthermore, as is the case with computer programmes today, English cannot usually function as an effective "parser", an intermediate translation modus, between other languages. If English is used as a "parser" for translations between Slavic languages, the effects are often totally wrong, and at times not only incorrect, but also very perverse. For example, if one tries to translate the Croatian word Slaveni ("Slavic peoples") into Russian via the official Google translation system, the result in Russian would be pабы (= raby), "slaves" 22 .

\section{Zonal constructed languages - a solution to globalisation}

Globalisation under English domination, is not a realistic way of linking together world cultures so as to increase ideas, innovations and improve international relations between various peoples. English is a specific cultural language, which is fine. But this means that it should not be imposed as a general international language, or as something similar to Esperanto.

Unfortunately, Esperanto is also quite specific, due to the way in which it was constructed, which is not really similar to natural languages. It is positive, since it is formally neutral, but the degree to which it could aid in the establishment of a genuine form of globalisation, in which various languages and cultures have a role (and not just one), is questionable. However, in the present period several "zonal languages" have been constructed, and these creations can

\footnotetext{
${ }^{22}$ There are, in general, many other errors when English is used as a "parser" between other languages that are, between themselves, more or less linguistically related, yet distant from English, which has certain "creole" traits. In this framework, some word shifts that occurred in English in the last decades produced additional problems. For example, we know also the term "smart". Several years ago the German firm Mercedes-Benz began producing small cars, and then the Swiss-Lebanese entrepreneur and one of the founders of CEO and the "Swatch Group", Nicolas Hayek (1928-2010), who motivated this move, apparently "paired up with Mercedes Benz, which is where the M is coming from. The ART is the art form of the vehicle". This citation is from an e-mail which the author of this article received when he saw that the "Smart Car" production began to cross/eliminate the letter "a" in the name (due to stylist thoughts), and them in the Slavic world "Smart Car" turned into "smrt", i.e. "death" in the Slavic language. The author, EH, wrote this to the firm in its US base, and received a comment "We appreciate the opportunity to respond" (MBUSA Customer Support, $10^{\text {th }}$ October 2016). This was more or less, last year. After this information, the author (EH), by chance took a look at the Internet site in regard to the original etymology of the English term "smart" (https://www.etymonline.com/word/smart). The result was quite shocking. The English term smart originally meant "painful, severe, stinging, causing a sharp pain", and despite the Internet text, the root was most likely something similar to the basis/root $m r t$, which is the origin of the Latin term, Italian morte, French mort, and the Slavic words: Croat, Czech, Slovenian, Serbian smrt, Russian cмерть, Polish śmierć. Apparently, according to the Internet etymological site, "smart" was first attested in 1972 as "good sense, intelligence", although, in Dutch it still has the same original meaning ("sharp pain") and it still corresponds to the German word Schmerz, "pain" (previous Internet note). Naturally, this is a mess. One can imagine, that pain and death, via English, means "intelligence", which is - certainly not normal.
} 
serve as structures for precise computer translations, which would assure both the natural development of existing world languages and also bring such languages to the level of international communication. For example, the "zonal constructed" Slavic language, Neoslavonic, used as a translation "parser" would enable international communication between all Slavic languages. In turn it would give a great advantage to languages with a relative small number of speakers (such as Slovenian, or Sorbian).

Zonal constructed languages are very important, since they assure ties between languages and cultures all over the world. If many such constructions would be produced, the global correlation between diverse populations would be very positive. This would assure a highly positive globalisation tendency throughout the world.

\section{References}

Cavalli-Sforza, L. L. (1996). Geni, popoli e lingue. Milano: Adelphi [Genes, peoples, and languages. New York: North Point Press, 2000].

Geertz, C. (1973). The interpretation of cultures. New York: Basic Books.

Gluhak, A. (1993). Hrvatski etimološki rječnik [Croatian etymological dictionary]. Zagreb: August Cesarec

Heršak, E. (2003). Globalisation and the Croatian code. In: Matko Meštrović (ed.), Globalization and its reflections on/in Croatia (pp. 131-148). New York: Global Scholarly Publications.

Ivanović, M. (2008). Cultural tourism. Capetown: Juta \& Company.

Le Goff, J. (1982). Intervista sulla storia [Interview in regard to history]. Roma-Bari: Laterza.

Kroeber, A. L., \& Kluckhohn, C. (1952). Culture: A critical review of concepts and definitions. Harvard University Peabody Museum of American Archaeology and Ethnology Papers. Cambridge, Massachusetts.

London, J. (1909). Too much English, Woman’s Home Companion, 34(4) (April). New York.

Mercier, L.-S. (1771). L'An 244O, rêve s'il en fut jamais [The year 2440: A dream if ever there was one]. London (see https://fr.wikisource.org/wiki/L'An_deux mille quatre cent quarante).

Mill, J. S. (1861). Considerations on representative government. London: Parker, Son and Bourn, West Strand.

Mlinarić, D., Faričić, J., \& Mirošević, L. (2012). Historijsko-geografski kontekst nastanka Lučićeve karte Illyricum hodiernum [The historic-geographic context pertaining to the origin of Lučić's map Illyricum Hodiernum], Geoadria, 17(2), 145-176.

Orwell, G. (1946). Politics and the English language, Horizon, April, pp. 252-265. London.

Phillipson, R. (1992). Linguistic imperialism. Oxford: University Press.

Phillipson, R. (2008). Lingua franca or lingua frankensteinia? English in European integration and globalisation, World Englishes, 27(2), 250-267.

Sapir, E. (1986). The function of an international auxiliary language, in: D.G. Mandelbaum (ed.), Language and Personality. Selected Essays. Berkeley: University of California Press.

Seidensticker, B. (2006). Future hype. The myths of technology change. San Francisco: Berrett-Koehler.

Simms, B. (2014). Europe: The struggle for supremacy, 1453 to the present. London: Penguin.

Wierzbicka, A. (2014). Imprisoned in English. The hazards of English as a default language. Oxford: University Press. 
E. Heršak - Zonal Constructed Language Contacts ...

c O A $\mathrm{s}$ 